\title{
Effects of sciatic nerve transection on glucose uptake in the presence and absence of lactate in the frog dorsal root ganglia and spinal cord
}

\author{
Rigon, F. ${ }^{a}$, Horst, A. ${ }^{b}$, Kucharski, LC. ${ }^{b}$, Silva, RSM. ${ }^{b}$, \\ Faccioni-Heuser, MC. ${ }^{c}$ and Partata, WA. ${ }^{b *}$ \\ ${ }^{a}$ Departamento de Fisioterapia, Universidade Luterana do Brasil - ULBRA, Rua Universitária, 1900, \\ Torres - Parque Balonismo, CEP 95560000, Torres, RS, Brazil \\ 'Departamento de Fisiologia, Instituto de Ciências Básicas da Saúde - ICBS, Universidade Federal do \\ Rio Grande do Sul - UFRGS, Rua Sarmento Leite, 500, Farroupilha, CEP 90040060, Porto Alegre, RS, Brazil \\ 'Departamento de Ciências Morfológicas, Instituto de Ciências Básicas da Saúde - ICBS, Universidade Federal do \\ Rio Grande do Sul - UFRGS, Rua Sarmento Leite, 500, Farroupilha, CEP 90040060, Porto Alegre, RS, Brazil \\ *e-mail: partataw@gmail.com
}

Received: December 12, 2012 - Accepted: June 13, 2013 - Distributed: November 30, 2014

(With 3 figures)

\begin{abstract}
Frogs have been used as an alternative model to study pain mechanisms because the simplicity of their nervous tissue and the phylogenetic aspect of this question. One of these models is the sciatic nerve transection (SNT), which mimics the clinical symptoms of "phantom limb", a condition that arises in humans after amputation or transverse spinal lesions. In mammals, the SNT increases glucose metabolism in the central nervous system, and the lactate generated appears to serve as an energy source for nerve cells. An answerable question is whether there is elevated glucose uptake in the dorsal root ganglia (DRG) after peripheral axotomy. As glucose is the major energy substrate for frog nervous tissue, and these animals accumulate lactic acid under some conditions, bullfrogs Lithobates catesbeianus were used to demonstrate the effect of SNT on DRG and spinal cord 1-[ $\left.{ }^{[4} \mathrm{C}\right] 2$-deoxy-D-glucose $\left({ }^{14} \mathrm{C}-2-\mathrm{DG}\right)$ uptake in the presence and absence of lactate. We also investigated the effect of this condition on the formation of ${ }^{14} \mathrm{CO}_{2}$ from ${ }^{14} \mathrm{C}$-glucose and ${ }^{14} \mathrm{C}$-L-lactate, and plasmatic glucose and lactate levels. The 3-O- $\left[{ }^{14} \mathrm{C}\right]$ methyl-D-glucose $\left({ }^{14} \mathrm{C}-3-\mathrm{OMG}\right)$ uptake was used to demonstrate the steady-state tissue/medium glucose distribution ratio under these conditions. Three days after SNT, ${ }^{14} \mathrm{C}-2$-DG uptake increased, but ${ }^{14} \mathrm{C}-3$-OMG uptake remained steady. The increase in ${ }^{14} \mathrm{C}-2$-DG uptake was lower when lactate was added to the incubation medium. No change was found in glucose and lactate oxidation after SNT, but lactate and glucose levels in the blood were reduced. Thus, our results showed that SNT increased the glucose metabolism in the frog DRG and spinal cord. The effect of lactate on this uptake suggests that glucose is used in glycolytic pathways after SNT.
\end{abstract}

Keywords: peripheral nerve lesion, 1-[ $\left.{ }^{14} \mathrm{C}\right]$ 2-deoxy-D-glucose, 3-O- $\left[{ }^{14} \mathrm{C}\right]$ methyl-D-glucose.

\section{Efeito da secção do nervo isquiático sobre a captação de glicose na presença e ausência de lactato em gânglio da raiz dorsal e medula espinhal de rãs}

\section{Resumo}

As rãs são usadas como modelos experimentais alternativos no estudo da nocicepção, tanto pela simplicidade do seu tecido nervoso como por permitirem uma abordagem filogenética sobre o tema. Um desses modelos é a secção do nervo isquiático (SNI), o qual simula os sintomas clínicos do "membro fantasma", uma condição que ocorre nos humanos após amputação ou secção completa da medula espinal. Em mamíferos, a SNI aumenta o metabolismo da glicose no sistema nervoso central, e o lactato é uma fonte energética para as células nervosas. Porém é desconhecido se essa é a situação em gânglio da raiz dorsal (GRD). Como a glicose é o principal substrato energético para o tecido nervoso de rãs, e a concentração plasmática de lactato está aumentada nesses animais em distintas situações, a rã-touro Lithobates catesbeianus foi usada para demonstrar os efeitos da SNI sobre a captação de 1-[ $\left[{ }^{14} \mathrm{C}\right]$ 2-deoxi-D-glicose $\left({ }^{14} \mathrm{C}-2-\mathrm{DG}\right)$, na presença e ausência de lactato, em GRD e medula espinal. Foram demonstrados ainda os efeitos dessa condição experimental sobre a formação de ${ }^{14} \mathrm{CO}_{2}$ a partir de ${ }^{14} \mathrm{C}$-glicose e e ${ }^{14} \mathrm{C}$-L-lactato, e a concentração plasmática de glicose e lactato. A captação de 3-O- $\left[{ }^{14} \mathrm{C}\right]$ metil-D-glicose $\left({ }^{14} \mathrm{C}-3-\mathrm{OMG}\right)$ foi usada para demonstrar a relação tecido/meio estável da glicose nessas condições. A captação de ${ }^{14} \mathrm{C}-2$-DG aumentou três dias após a SNI, sem qualquer alteração na captação de ${ }^{14} \mathrm{C}-3$-OMG. $\mathrm{O}$ aumento foi reduzido quando o lactato foi acrescentado ao meio de incubação. A taxa de oxidação da glicose e do lactato não modificou após SNI, mas houve redução na concentração plasmática de glicose e lactato. Assim, a SNI aumenta o metabolismo da glicose no GRD e medula espinal de rãs. Os efeitos do lactato sobre essa captação sugerem o uso da glicose na via glicolítica após a SNI.

Palavras-chave: lesão nervosa periférica, 1-[ $\left[{ }^{14} \mathrm{C}\right]$ 2-deoxi-D-glicose, 3-O- $\left[{ }^{14} \mathrm{C}\right]$ metil-D-glicose. 


\section{Introduction}

The sciatic nerve transection (SNT) model mimics the clinical symptoms of "phantom limb", a condition that arises in humans after amputation or transverse spinal lesions (Klusáková and Dubový, 2009). Studies have demonstrated that this condition causes structural, electrophysiological, molecular and metabolic changes in mammalian dorsal root ganglia (DRG) cells and spinal cord. These changes include progressive loss of cells (Oliveira, 2001; Jiang and Jakobsen, 2010), proliferation and activation of satellite glial cells (Hanani, 2005) and reorganisation of the metabolic priorities of neural cells (Enes et al., 2010). There is evidence that the transection of facial and hypoglossal nerves produces a significant increase in glucose utilisation in motor nuclei of these nerves in rats (Kreutzberg and Emmert, 1980). Changes in glucose uptake also occurred in rat auditory pathways after bilateral ablation of the cochlea (Ahn et al., 2004). An answerable question is whether there is elevated glucose uptake in the dorsal root ganglia (DRG) after peripheral axotomy.

One consequence of the SNT is an increase in vesicular glutamate transporter-2 $\left(\mathrm{VGLUT}_{2}\right)$ in the dorsal root fibres of rats (Brumovsky et al., 2007). Studies have demonstrated that when more glutamate is released, more lactate is also generated, which may serve as an energy source for nerve cells (Schurr et al., 1999; Schurr and Payne, 2007; Barros and Deitmer, 2010; Schurr and Gozal, 2012).

Amphibians have been used as an alternative model to study pain mechanisms (Stevens, 2004; Stevens et al., 2007; Stevens et al., 2009; Coble et al., 2011; Ohkita et al., 2012; Saito et al., 2012), for several reasons. Stevens (2004) noted that the use of these animals provides a phylogenetic perspective on the mechanisms of pain research. Other aspects include the simplicity of the amphibian central nervous system and the economic advantage of using these animals. In addition, the metabolic changes are much slower in frog brain than those found in the mammalian brain (McDougal et al., 1968). Thus, frog nervous tissue offers a unique model to examine the relationship between SNT and glucose metabolism.

The American bullfrog Lithobates catesbeianus is an aquatic amphibian native to the United States, which was imported into Brazil during the early 1930s and has been raised in this country ever since (Rocha and Branco, 1998). The ease of acquiring specimens of $L$. catesbeianus has allowed us to use this animal as an experimental model in our studies. One of the experimental situations is the SNT. In previous studies, members of our laboratory have demonstrated changes in different neurotransmitters and neuropeptides after SNT. Many of these alterations share similarities with those observed in mammals (Partata et al., 2002; Guedes et al., 2004a, b). As glucose has been considered the major energy substrate for the frog brain (McDougal et al., 1968), glucose transporters (Glut) types 1 and 3 are found in the nervous tissue of these animals (Rigon et al., 2013) and they accumulate lactic acid under some conditions (Warren and Jackson, 2005). Therefore we used frogs to demonstrate the effect of SNT on frog DRG 1- $\left[{ }^{14} \mathrm{C}\right]$ 2-deoxy-D-glucose $\left({ }^{14} \mathrm{C}\right.$-2-DG) uptake in the presence and absence of lactate. In addition, the formation of ${ }^{14} \mathrm{CO}_{2}$ from ${ }^{14} \mathrm{C}$-glucose and ${ }^{14} \mathrm{C}$ - L-lactate, and elevated glucose and lactate plasma levels after SNT were demonstrated. The uptake of 3-O- $\left[{ }^{14} \mathrm{C}\right]$ methyl-D-glucose $\left({ }^{14} \mathrm{C}-3-\mathrm{OMG}\right)$ was used to demonstrate the steady-state tissue/medium glucose distribution ratio under these conditions. All these parameters were also analysed in the lumbosacral spinal cord, where most of the afferent fibres of the sciatic nerve enter and the motor neurons of this nerve are located (Penicnak and Dunlap, 1962; Sutherland and Nunnemacher, 1974). We used ${ }^{14} \mathrm{C}-2$-DG because this molecule is a glucose analogue that is incorporated into neural tissue by the same pathways, and at the same rate, as glucose, but it is not completely metabolised and therefore becomes trapped in the cell as deoxyglucose-6-phosphate and is not further metabolised by the glycolytic pathway. All experiments were performed three days after SNT, because previous studies demonstrated that functional changes in frog nervous tissue are already present three days following axotomy (Partata et al., 2002; Guedes et al., 2004a, b).

\section{Material and Methods}

\subsection{Experimental animals}

Specimens of adult male bullfrogs Lithobates catesbeianus weighing 100-200 g were obtained from RANASUL (Imbé, RS). Upon arrival at the laboratory they were housed in cages with water and kept under natural light at $12-25^{\circ} \mathrm{C}$ temperature. The animals were fed ad libitum with specific food which was offered on a vibration plate to move the pellets. The animals remained in these laboratory conditions for at least 2 weeks before they were used in the experiments. The frogs were divided into three experimental groups (six animals/group): naive (animals that did not undergo surgical manipulation), Sham (animals in which all surgical procedures to expose the sciatic nerve were used except transection of this nerve) and SNT (animals in which the sciatic nerve was exposed and transected). For surgical procedures, frogs were anesthetised with prilocaine $(0.1 \mathrm{ml} / 100 \mathrm{~g}$ body weight $)$. In the SNT group, the right sciatic nerve was exposed and transected approximately $5 \mathrm{~mm}$ distal to the sciatic notch. In all animals the wound was closed and the animals were killed 3 days after the procedure. The results reported here were obtained between April and September. The experimental protocol followed the NIH Guide for the Care and Use of Laboratory Animals (NIH publication 85-23 revised 1985). All efforts were made to minimise the number of animals used and their suffering. The experimental protocol was approved by the graduate committee of the Institute of Basic Health Sciences, Federal University of Rio Grande do Sul.

\subsection{Glucose uptake}

Ganglia were excised from naive, sham and transected frogs over a period of $3 \mathrm{~min}$ and rapidly transferred to sterile chilled Ringer's solution. The Ringer's solution was 
composed of $110 \mathrm{mM} \mathrm{NaCl}, 1 \mathrm{mM} \mathrm{KCl}, 2 \mathrm{mM} \mathrm{CaCl}_{2}$ and $2 \mathrm{mM} \mathrm{NaHCO}_{3}$. The $\mathrm{pH}$ was adjusted to 7.4 (Kaloyianni and Doukakis, 2003). Glucose was not added to guarantee the availability of glucose transporter as done in other studies (Machado et al., 1991; Kaloyianni and Doukakis, 2003; Fraga et al., 2010). Each ganglion was placed in chilled Eppendorf tubes with known weight, and weighed again. The difference was taken as the ganglion weight and the value used to calculate the uptake. The tissues were then incubated at $25^{\circ} \mathrm{C}$ with constant shaking in $250 \mathrm{ml}$ of frog Ringer`s solution in the presence of $0.15 \mu \mathrm{Ci}$ of ${ }^{14} \mathrm{C}-2-\mathrm{DG}$ (39 $\mathrm{mCi} / \mathrm{mmol}$, Amersham). Incubation in the presence of $0.15 \mu \mathrm{Ci}$ of $3-\mathrm{O}-\left[{ }^{14} \mathrm{C}\right]$ methyl-D-glucose $\left({ }^{14} \mathrm{C}-3-\mathrm{OMG}\right)$ $(53 \mathrm{mCi} / \mathrm{mmol}$, Amersham) was used in the same conditions to determine the steady-state tissue/medium glucose distribution ratio (Dienel et al., 1997). Incubations were performed in a Dubnoff incubator with an atmosphere of $\mathrm{O}_{2}: \mathrm{CO}_{2}(95: 5, \mathrm{v} / \mathrm{v})$. Following the incubations, the tissues were removed from the medium, rinsed twice in cold frog Ringer`s solution (without radiolabelled products), blotted on filter paper and immediately transferred to screw-cap tubes containing $1 \mathrm{ml}$ of distilled water, and alternately frozen and boiled three times. Aliquots $(100 \mathrm{ml})$ of this solution and of the incubation medium were used for radioactivity counts in toluene-TritonX-100 (2:1, v/v) $-0.4 \%$ PPO $-0.01 \%$ POPO. Radioactivity was measured in a liquid scintillation spectrometer (LKB Wallac scintillation counter). Results were expressed as tissue/medium (T/M) rate, i.e., dpm/ml of tissue fluid divided by $\mathrm{dpm} / \mathrm{ml}$ of incubation medium.

To facilitate visualisation of the sequence of experiments, they are described separately below, in the sequence in which they were performed.

Experiment 1: Time curve. DRG and spinal cord from naive frogs were incubated under the above conditions with $0.15 \mu \mathrm{Ci}$ of ${ }^{14} \mathrm{C}-2-\mathrm{DG}$ or ${ }^{14} \mathrm{C}-3$-OMG for $5,15,60$ and $120 \mathrm{~min}$.

Experiment 2: Effects of SNT on ${ }^{14} \mathrm{C}-2-\mathrm{DG}$ uptake. Three days after the peripheral injury, the DRG and lumbosacral spinal cord were quickly dissected out and incubated, separately, under the above conditions. The ganglia obtained from the same spinal-cord segment were separated ipsilaterally and contralaterally to the nerve lesion. The tissues were incubated with $0.15 \mu \mathrm{Ci}{ }^{14} \mathrm{C}-2$ DG or ${ }^{14} \mathrm{C}-3-\mathrm{OMG}$ for $60 \mathrm{~min}$ under the same conditions initially described.

Experiment 3: Effects of lactate on ${ }^{14} \mathrm{C}$-2-DG uptake. The tissues were incubated with $0.15 \mu \mathrm{Ci}$ of ${ }^{14} \mathrm{C}$-2-DG plus $10 \mathrm{mM}$ lactate for $60 \mathrm{~min}$ under the same conditions initially described. This value was chosen for lactate because it was used in other studies with the ganglion (Larrabee, 1980, 1996).

\subsection{Formation of $14 \mathrm{CO} 2$}

DRG obtained from the same spinal cord segment (separately, ipsilaterally and contralaterally to the nerve lesion) and the lumbosacral spinal cord were incubated in flasks sealed with rubber caps at $25^{\circ} \mathrm{C}$, with constant shaking, in $1 \mathrm{ml}$ of frog Ringer's solution, $\mathrm{pH}$ 7.4. To this incubation medium were added $0.15 \mu \mathrm{Ci}\left[\mathrm{U}-{ }^{14} \mathrm{C}\right]$ L-lactate (108.30 mCi/mmol, Amersham) plus $10 \mathrm{mM}$ of unlabelled lactate or $0.15 \mathrm{mci}\left[\mathrm{U}-{ }^{14} \mathrm{C}\right]$ glucose $(115.00 \mathrm{mCi} / \mathrm{mmol}$, Amersham) plus $10 \mathrm{mM}$ glucose (Torres et al., 2001). Incubation was conducted in an atmosphere of $\mathrm{O}_{2}: \mathrm{CO}_{2}$ $(95: 5, \mathrm{v} / \mathrm{v})$ for $60 \mathrm{~min}$. After addition of the unlabelled lactate or glucose, the $\mathrm{pH}$ of the incubation medium was determined. A saturating lactate or glucose concentration was used for $\mathrm{CO}_{2}$ production. 3MM Whatman papers were placed into glass wells inserted in the rubber stoppers of the flasks. Incubation was stopped by adding $0.2 \mathrm{ml}$ of $50 \%$ TCA through the rubber cap. Then, $0.2 \mathrm{ml}$ of $2 \mathrm{M}$ $\mathrm{NaOH}$ was injected into the central wells to trap ${ }^{14} \mathrm{CO}_{2}$. These were small glass wells placed inside the flasks and above the level of the incubation medium. The flasks were shaken for a further $60 \mathrm{~min}$ at $25^{\circ} \mathrm{C}$ to trap ${ }^{14} \mathrm{CO}_{2}$ after which the contents of the centre well were transferred to vials containing toluene-TritonX-100 (2:1, v/v) - 0.4\% PPO $-0.01 \%$ POPO and assayed for $\mathrm{CO}_{2}$ radioactivity in a liquid scintillation counter. The values of ${ }^{14} \mathrm{CO}_{2}$ production were expressed as mmol of ${ }^{14} \mathrm{C}$-L-lactate or ${ }^{14} \mathrm{C}$-glucose converted to ${ }^{14} \mathrm{CO}_{2}$. mg of tissue ${ }^{-1} \cdot \mathrm{h}^{-1}$ of incubation.

\subsection{Determination of plasma lactate and glucose}

Samples of plasma were obtained from naive and transected frogs. Glucose blood concentration was determined by the glucose oxidase method with a Labtest kit (Brazil), and blood lactate was determined with a Bioclin kit (Quibasa, Brazil). Values of glucose and lactate were expressed in $\mathrm{mmol} / \mathrm{L}$.

\subsection{Statistical analysis}

The results obtained from frog ganglia with peripheral lesion were compared between the ipsilateral and contralateral ganglia and with naive and sham ganglia. For the spinal cord, the results were compared among naive, sham and injured frogs. Data were analysed by one-way ANOVA followed by Tukey's post hoc test. The results for plasma were analysed by an independent Student's $t$ test. The significance level was $\mathrm{P}<0.05$. All tests were performed with the Statistical Package for the Social Sciences, version 13.0 (SPSS).

\section{Results}

\subsection{Glucose uptake and $14 C O 2$ formation}

In DRG and spinal cord, the ${ }^{14} \mathrm{C}$-2-DG uptake was not affected by the incubation time. The ${ }^{14} \mathrm{C}-3-\mathrm{OMG}$ uptake showed no change in DRG and spinal cord (Table 1).

In spinal cords from naive animals, the ${ }^{14} \mathrm{C}-2-\mathrm{DG}$ uptake was 3.5 times higher than in DRG (Figure 1). This uptake changed in DRG when lactate was added to the incubation medium. Although ${ }^{14} \mathrm{C}-2-\mathrm{DG}$ uptake decreased by around $36 \%$ in DRG of naive animals, it remained the same in the spinal cord (Figures 1a, b, c).

The ${ }^{14} \mathrm{C}-2-\mathrm{DG}$ uptake was increased in DRG three days after SNT. The increase of ${ }^{14} \mathrm{C}-2-\mathrm{DG}$ uptake was $223 \%$ and $141 \%$ in the ipsilateral and contralateral DRG, 
Table 1. Uptake of 1-[ $\left[{ }^{14} \mathrm{C}\right]$ 2-deoxy-D-glucose and 3-O- $\left[{ }^{14} \mathrm{C}\right]$ methyl-D-glucose by dorsal root ganglia (DRG) and spinal cord (SC) from naive frogs.

\begin{tabular}{ccccc}
\hline \multirow{2}{*}{ Time (min) } & \multicolumn{2}{c}{$\mathbf{1 -}\left[{ }^{14} \mathbf{C}\right]$} & 2-deoxy-D-glucose & \multicolumn{2}{c}{ 3-O- $\left[{ }^{14} \mathbf{C}\right]$ methyl-D-glucose } \\
\cline { 2 - 5 } & DRG & SC & DRG & SC \\
\hline 5 & $0.22 \pm 0.06$ & $0.22 \pm 0.02$ & $0.23 \pm 0.06$ & $0.26 \pm 0.06$ \\
15 & $0.22 \pm 0.02$ & $0.26 \pm 0.03$ & $0.29 \pm 0.07$ & $0.27 \pm 0.07$ \\
60 & $0.22 \pm 0.04$ & $0.47 \pm 0.02$ & $0.39 \pm 0.06$ & $0.31 \pm 0.09$ \\
120 & $0.25 \pm 0.05$ & $0.74 \pm 0.08$ & $0.38 \pm 0.06$ & $0.33 \pm 0.07$ \\
\hline
\end{tabular}

These tissues were incubated at $25^{\circ} \mathrm{C}$ for different times and were processed as indicated under Materials and Methods. Data are given as means \pm SEM. Results are expressed as tissue/medium (T/M) rate, i.e., dpm $/ \mathrm{ml}$ of tissue fluid divided by dpm $/ \mathrm{ml}$ of incubation medium. No significant difference was found (one way ANOVA).

respectively (Figure 1a), compared to DRG from the naive group. No significant change occurred in the sham group, showing that the effect is specific to SNT. Likewise, the ${ }^{14} \mathrm{C}-2-\mathrm{DG}$ uptake did not change significantly in the spinal cord of the sham group. The uptake increased in the spinal cord of transected animals. The increase was approximately $41 \%$ after axotomy (Figure 1b). No change was found in this uptake in DRG and spinal cord from naive frogs, showing that this effect is specific to SNT.

In the DRG, the increase in ${ }^{14} \mathrm{C}-2-\mathrm{DG}$ uptake caused by SNT was smaller in the presence of lactate in the incubation medium. This increase was approximately $58 \%$ in the ipsilateral and contralateral ganglia compared to those of the naive group (Figure 1c). The values of ${ }^{14} \mathrm{C}-2-\mathrm{DG}$ uptake in the presence of lactate decreased by around $57 \%$ and $46 \%$ in the ipsilateral and contralateral ganglia, respectively, compared to ganglia from SNT frogs (Figures 1a, c). Similarly, ${ }^{14} \mathrm{C}-2-\mathrm{DG}$ uptake in the spinal cord was also reduced in the presence of lactate, by about $50 \%$ compared to the naive group (Figure 1c), but by $59 \%$ compared to the spinal cords from SNT frogs (Figures 1b, c).

Both DRG and spinal cord use lactate, but the DRG rate was about 100 times higher than in the spinal cord (Figure 2a). Sciatic nerve transection failed to induce any significant changes in the formation of ${ }^{14} \mathrm{CO}_{2}$ from ${ }^{14} \mathrm{C}$-Llactate in these tissues (Figure 2a). The rate of ${ }^{14} \mathrm{C}$-glucose oxidation did not change after SNT (Figure 2b).

\subsection{Lactate and glucose plasma levels}

SNT significantly decreased lactate and glucose plasma levels, but the reduction was greater for lactate than for glucose. Lactate levels decreased by about 65\% (Figure 3a), while glucose levels decreased by about 39\% (Figure 3b).

\section{Discussion}

Our results demonstrated that SNT induced an increase in ${ }^{14} \mathrm{C}$-2-DG uptake, but no change in ${ }^{14} \mathrm{C}$-3-OMG uptake in the frog DRG and spinal cord. The increase in ${ }^{14} \mathrm{C}-2-$ DG uptake was smaller when lactate was added to the incubation medium. No change was found in glucose and lactate oxidation after SNT, but this experimental condition reduced the blood levels of lactate and glucose. Thus, the frog DRG and spinal cord were able to transport
${ }^{14} \mathrm{C}-2-\mathrm{DG}$ efficiently. The absence of changes in 3-OMG uptake under our experimental conditions demonstrates the steady-state tissue/medium glucose distribution ratio during the incubations. In turn, the lack of change in ${ }^{14} \mathrm{C}$-2-DG uptake over time may be a function of the animal species studied. The uptake of ${ }^{14} \mathrm{C}$-2-DG by the turtle thyroid incubated at $25^{\circ} \mathrm{C}$ increased markedly at 240 min (Machado et al., 1991).

Interestingly, ${ }^{14} \mathrm{C}-2-\mathrm{DG}$ transport decreased when lactate was added to the incubation medium. It has been demonstrated that the perineurium surrounding the frog DRG contains fewer cell layers and more gaps in these layers than the mammalian perineurium (Matsumoto and Rosenbluth, 1988). According to these authors, these characteristics increase the susceptibility of DRG to circulating molecules and allow trophic factors, hormones and nutrients to reach the ganglion cells more readily. This characteristic would contribute to higher utilisation of lactate in the DRG than the spinal cord. In this tissue, the blood-brain-barrier has many of the properties of a tight epithelium, including the presence of tight junctions and specific transport mechanisms (Abbott, 2005). The moredeveloped barrier in the spinal cord may limit the use of lactate by this tissue. By using less lactate, the spinal-cord tissue appears to depend principally on glucose, which explains the elevated ${ }^{14} \mathrm{C}-2-\mathrm{DG}$ uptake and the absence of change in the uptake when lactate was added to the incubation medium. Higher glucose utilisation by the spinal cord than the DRG also occurs in rats (Kadekaro et al., 1985). The use of lactate as an energy substrate by the frog DRG also concords with observations from studies of mammals and non-mammals. Previous studies showed a preferential use for lactate in avian, mammalian and human neuronal oxidative metabolism (Larrabee, 1980, 1996; BouzierSore et al., 2003, 2006; Pellerin and Magistretti, 2012).

After SNT, we found an increase in ${ }^{14} \mathrm{C}-2-\mathrm{DG}$ uptake in the frog DRG and lumbosacral spinal cord. A similar result was observed in mammalian cephalic nerves after peripheral lesion (Kreutzberg and Emmert, 1980; Singer and Mehler, 1980; Mao et al., 1993; Moreno-Flores et al., 1997; Moran and Graeber, 2004; Gómez et al., 2011). Since ${ }^{14} \mathrm{C}-2-\mathrm{DG}$ is a glucose analogue that is incorporated into neural tissue by the same pathways, and at the same rate, as glucose, the increase in ${ }^{14} \mathrm{C}$-2-DG uptake possibly reflects the increased energy demand to meet the metabolic requirements of 

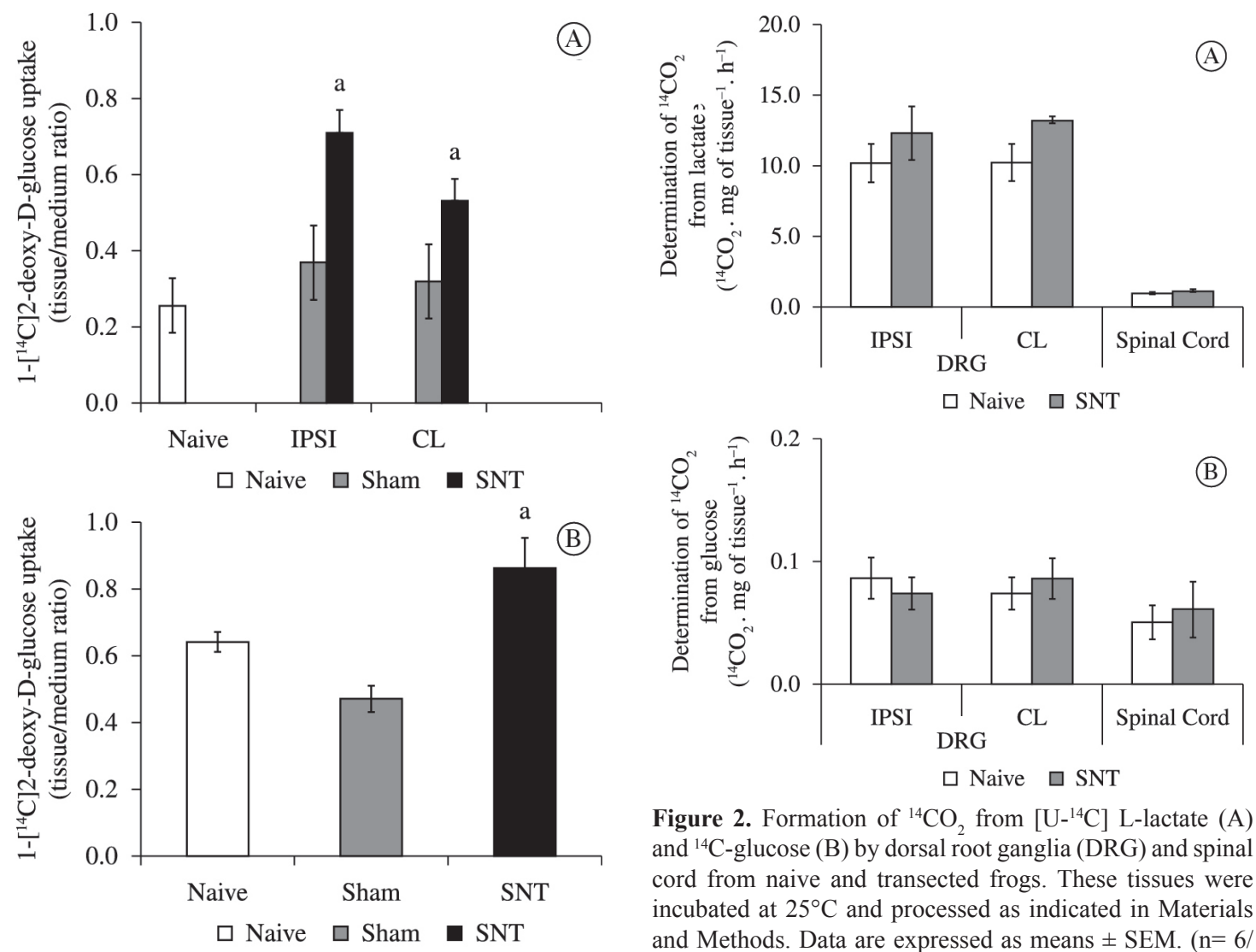

Figure 2. Formation of ${ }^{14} \mathrm{CO}_{2}$ from $\left[\mathrm{U}_{-}{ }^{14} \mathrm{C}\right]$ L-lactate (A) and ${ }^{14} \mathrm{C}$-glucose (B) by dorsal root ganglia (DRG) and spinal cord from naive and transected frogs. These tissues were incubated at $25^{\circ} \mathrm{C}$ and processed as indicated in Materials and Methods. Data are expressed as means \pm SEM. $(n=6 /$ group). Results are expressed as (A) $\mathrm{mmol}{ }^{14} \mathrm{C}$-L-lactate converted to ${ }^{14} \mathrm{CO}_{2} \cdot \mathrm{mg}$ of tissue ${ }^{-1} \cdot \mathrm{h}^{-1}$ of incubation and (B) ${ }^{14} \mathrm{CO}_{2} \cdot \mathrm{mg}$ of tissue ${ }^{-1} \cdot \mathrm{h}^{-1}$ of incubation. No significant difference was found (one-way ANOVA). IPSI, ipsilateral; CL, contralateral; SNT, sciatic nerve transection.

the frog nervous tissue after SNT. In mammals, glucose incorporation into neurons or phosphorylation of glucose appears to be one of the earliest changes in metabolism affected by the signal for regeneration (Kreutzberg and Emmert, 1980; Singer and Mehler, 1980; Mao et al., 1993; Moreno-Flores et al., 1997).

After SNT, the DRG ${ }^{14} \mathrm{C}-2$-DG uptake was decreased when lactate was added to the incubation medium. A similar response also occurred in the spinal cord. Interestingly, the conversion of ${ }^{14} \mathrm{C}$-L-lactate and ${ }^{14} \mathrm{C}$-glucose to ${ }^{14} \mathrm{CO}_{2}$ did not change after SNT in these tissues. This lack of change may be due to glycolysis. The rise in ${ }^{14} \mathrm{C}-2$-DG uptake with SNT, but not $\mathrm{CO}_{2}$ production, suggests that the cells may be producing lactate from the glucose metabolised, which explains, in part, the low oxidation rate of glucose. The higher lactate oxidation may result from the efflux of lactate into a much larger volume, driven by glycolysis. It has been demonstrated that neurons produce lactate from glucose, despite the presence of lactate in the extracellular space and its simultaneous utilisation as an oxidative 

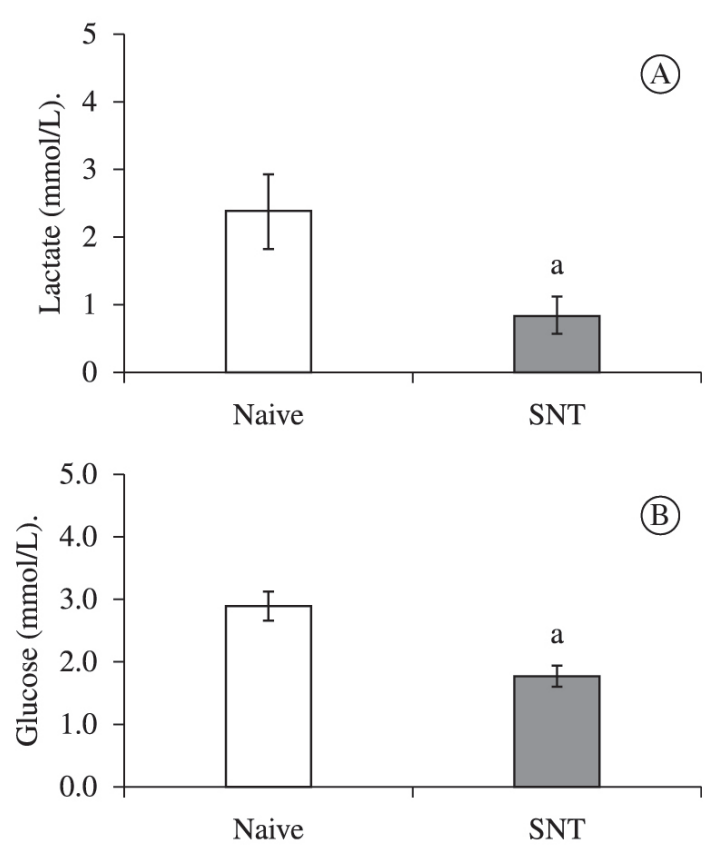

Figure 3. Blood lactate (A) and glucose (B) in naive and transected frogs. Lactate and glucose levels were determined as indicated under Materials and Methods. Results are expressed in $\mathrm{mmol} / \mathrm{L}$. (a) indicates significant difference compared with naive group $(\mathrm{P}<0.05$, one-way ANOVA followed by Tukey`s post hoc test). SNT, sciatic nerve transection.

substrate (Bouzier-Sore et al., 2003, 2006; Pellerin and Magistretti, 2012).

Interestingly, the reduction in ${ }^{14} \mathrm{C}-2-\mathrm{DG}$ uptake in the presence of lactate was around $50 \%$ in both DRG and spinal cord. As cited above, the morphological characteristics of the perineurium surrounding the frog DRG may contribute to the use of lactate that is present in the incubation medium. The use of lactate by the frog spinal cord may result from changes in the blood-spinal cord barrier. In mammals, the permeability of this barrier increased after injury (Beggs et al., 2010). According to these authors, the increased permeability of the blood-spinal cord barrier could allow entry of soluble factors that are normally excluded but that could contribute to pain hypersensitivity in the dorsal horn. This may be the situation in the frog spinal cord after SNT. Thus, we can advance the hypothesis that the use of lactate by the spinal cord after SNT is due to the change in the blood-spinal barrier permeability in the frog. Knowledge of the lactate uptake rate in the frog spinal cord submitted to SNT may help to clarify the role of this molecule under these conditions. The determination of this rate in the naive frog DRG and spinal cord will also be important for better understanding of the role of lactate in these tissues.

The low barrier of the frog DRG likely contributed to the bilateral increase in ${ }^{14} \mathrm{C}-2-\mathrm{DG}$ uptake in this tissue. The factors released by the regenerating nerve likely had access to both ganglia via the blood circulation. Regenerating peripheral nerves stimulate a marked increase in vascular permeability in the portion of the nerve distal to the lesion (Sparrow and Kiernan, 1981).

Interestingly, while the glucose/lactate ratio (mmol/ $\mathrm{mmol}$ ) was 1.2 in the plasma of naive frogs, it increased to 2.9 after SNT. This reduction in blood lactate levels may be related to muscle denervation. However, it has been demonstrated that denervation decreases the activities of succinate and lactate dehydrogenase in mammalian muscles, and down-regulates the expression of monocarboxylate transporters (Wilson et al., 1998; Juel and Halestrap, 1999). Another possibility may be the role of mineralised tissues of the frog in buffering lactic acidosis. The skeletal and endolymphatic calcium deposits function as buffers during anoxia and exercise-induced lactic acidosis in amphibians (Warren and Jackson, 2005). Additional studies should examine the relative contributions of these possible ways to reduce plasmatic lactate after SNT.

It might be assumed that the utilisation of plasma lactate is related to the anesthesia administered in the present study. However, although anesthesia does change hematological and cardiorespiratory parameters in the toad, they are recovered after 24 hours, and the blood lactate concentration does not change under these conditions (Andersen and Wang, 2002). Thus, the results of the present study are probably due to SNT and not to the anesthesia.

In conclusion, our results showed that SNT increases ${ }^{14} \mathrm{C}-2-\mathrm{DG}$ uptake. The increase in this uptake suggests high levels of functional activity of the frog DRG and spinal cord after SNT. Nevertheless, the amount of this increase was smaller in the presence of lactate. No change occurred in glucose and lactate oxidation after SNT, but glucose and lactate blood levels declined. Considering the effect of lactate on ${ }^{14} \mathrm{C}-2-\mathrm{DG}$ uptake, it can be speculated that the glucose may be supplying the glycolytic pathway. The similarities in the frog and mammalian physiological responses suggest that a similar situation may exist in mammals. However, further studies are necessary to extend out understanding of the role of lactate in DRG and spinal cord after SNT.

\section{Acknowledgements}

This study was supported by grants from the Fundação de Amparo à Pesquisa do Estado do Rio Grande do Sul (FAPERGS) and the Conselho Nacional de Desenvolvimento Científico e Tecnológico (CNPq).

\section{References}

ABBOTT, NJ., 2005. Dynamics of CNS barriers: evolution, differentiation, and modulation. Cellular and Molecular Neurobiology, vol. 25, no. 1, p. 5-23. http://dx.doi.org/10.1007/ s10571-004-1374-y. PMid:15962506

AHN, SH., OH, SH., LEE, JS., JEONG, JM., LIM, D., LEE, DS. and KIM, CS., 2004. Changes of 2-deoxyglucose uptake in the rat auditory pathway after bilateral ablation of the cochlea. Hearing Research, vol. 196, no. 1-2, p. 33-38. http://dx.doi.org/10.1016/j. heares.2004.05.012. PMid:15464299

ANDERSEN, JB. and WANG, T., 2002. Effects of anaesthesia on blood gases, acid-base status and ions in the toad Bufo marinus. 
Comparative Biochemistry and Physiology. Part A, Molecular \& Integrative Physiology, vol. 131, no. 3, p. 639-646. http://dx.doi. org/10.1016/S1095-6433(01)00498-6. PMid:11867289

BARROS, LF. and DEITMER, JW., 2010. Glucose and lactate supply to the synapse. Brain Research. Brain Research Reviews, vol. 63, no. 1-2, p. 149-159. http://dx.doi.org/10.1016/j.brainresrev.2009.10.002. PMid:19879896

BEGGS, S., LIU, XJ., KWAN, C. and SALTER, MW., 2010. Peripheral nerve injury and TRPV1-expressing primary afferent $\mathrm{C}$-fibres cause opening of the blood-brain barrier. Molecular Pain, vol. 6, no. 1, p. 3-12. http://dx.doi.org/10.1186/1744-8069-6-74.

BOUZIER-SORE, AK., VOISIN, P., CANIONI, P., MAGISTRETTI, PJ. and PELLERIN, L., 2003. Lactate is a preferential oxidative energy substrate over glucose for neurons in culture. Journal of Cerebral Blood Flow and Metabolism, vol. 23, no. 11, p. 12981306. http://dx.doi.org/10.1097/01.WCB.0000091761.61714.25. PMid:14600437

BOUZIER-SORE, AK., VOISIN, P., BOUCHAUD, V., BEZANCON, E., FRANCONI, JM. and PELLERIN, L., 2006. Competition between glucose and lactate as oxidative energy substrates in both neurons and astrocytes: a comparative NMR study. The European Journal of Neuroscience, vol. 24, no. 6, p. 1687-1694. http:// dx.doi.org/10.1111/j.1460-9568.2006.05056.x. PMid:17004932

BRUMOVSKY, P., WATANABE, M. and HÖKFELT, T., 2007. Expression of the vesicular glutamate transporters-1 and -2 in adult mouse dorsal root ganglia and spinal cord and their regulation by nerve injury. Neuroscience, vol. 147, no. 2, p. 469-490. http:// dx.doi.org/10.1016/j.neuroscience.2007.02.068. PMid:17577523

COBLE, DJ., TAYLOR, DK. and MOOK, DM., 2011. Analgesic effects of meloxicam, morphine sulfate, flunixin meglumine, and xylazine hydrochloride in African-clawed frogs (Xenopus laevis). Journal of the American Association for Laboratory Animal Science: JAALAS, vol. 50, no. 3, p. 355-360. PMid:21640031.

FRAGA, LS., SILVA, RS. and ZANCAN, DM., 2010. Control of carbohydrate metabolism in an anoxia-tolerant nervous system. Journal of Experimental Zoology. Part A, Ecological Genetics and Physiology, vol. 313, no. 9, p. 539-547. http://dx.doi.org/10.1002/ jez.624. PMid:20960558

DIENEL, GA., CRUZ, NF., ADACHI, K., SOKOLOFF, L. and HOLDEN, JE., 1997. Determination of local brain glucose level with [14C]methylglucose: effects of glucose supply and demand. The American Journal of Physiology, vol. 273, no. 5 Pt 1, p. E839-E849. PMid:9374668.

ENES, J., LANGWIESER, N., RUSCHEL, J., CARBALLOSAGONZALEZ, MM., KLUG, A., TRAUT, MH., YLERA, B., TAHIROVIC, S., HOFMANN, F., STEIN, V., MOOSMANG, S., HENTALL, ID. and BRADKE, F., 2010. Electrical activity suppresses axon growth through $\mathrm{Ca}(\mathrm{v}) 1.2$ channels in adult primary sensory neurons. Current Biology, vol. 20, no. 13, p. 1154-1164. http://dx.doi.org/10.1016/j.cub.2010.05.055. PMid:20579880

GÓMEZ, O., BALLESTER-LURBE, B., MESONERO, JE. and TERRADO, J., 2011. Glucose transporters GLUT4 and GLUT8 are upregulated after facial nerve axotomy in adult mice. Journal of Anatomy, vol. 219, no. 4, p. 525-530. http://dx.doi. org/10.1111/j.1469-7580.2011.01410.x. PMid:21740425

GUEDES, RP., MARCHI, MI., VIOLA, GG., XAVIER, LL., ACHAVAL, M. and PARTATA, WA., 2004a. Somatostatin-, calcitonin gene-related peptide, and gamma-aminobutyric acidlike immunoreactivitity in the frog lumbosacral spinal cord: distribution and effects of sciatic nerve transection. Comparative Biochemistry and Physiology. Part B, Biochemistry \& Molecular Biology, vol. 138, no. 1, p. 19-28. http://dx.doi.org/10.1016/j. cbpc.2004.01.004. PMid:15142533
GUEDES, RP., MARCHI, MI., ACHAVAL, M. and PARTATA, WA., 2004b. Complete sciatic nerve transection induces increase of neuropeptide Y-like immunoreactivity in primary sensory neurons and spinal cord of frogs. Comparative Biochemistry and Physiological. Part A, Molecular \& integrative physiology, vol. 139, no. 4, p. 461-467. http://dx.doi.org/10.1016/j.cbpb.2004.10.006. PMid:15596391

HANANI, M., 2005. Satellite glial cells in sensory ganglia: from form to function. Brain Research. Brain Research Reviews, vol. 48, no. 3, p. 457-476. http://dx.doi.org/10.1016/j.brainresrev.2004.09.001. PMid:15914252

JUEL, C. and HALESTRAP, AP., 1999. Lactate transport in skeletal muscle - role and regulation of the monocarboxylate transporter. The Journal of Physiology, vol. 517, no. Pt 3, p. 633-642. http:// dx.doi.org/10.1111/j.1469-7793.1999.0633s.x. PMid:10358105

KADEKARO, M., CRANE, AM. and SOKOLOFF, L., 1985. Differential effects of electrical stimulation of sciatic nerve on metabolic activity in spinal cord and dorsal root ganglion in the rat. Proceedings of the National Academy of Sciences of the United States of America, vol. 82, no. 17, p. 6010-6013. http://dx.doi. org/10.1073/pnas.82.17.6010. PMid:3862113

KALOYIANNI, M. and DOUKAKIS, I., 2003. Effect of adrenaline on glucose transport in red cells of Rana balcanica. General Physiology and Biophysics, vol. 22, no. 1, p. 69-80. PMid:12870702.

KLUSÁKOVÁ, I. and DUBOVÝ, P., 2009. Experimental models of peripheral neuropathic pain based on traumatic nerve injuries - an anatomical perspective. Annals of Anatomy = Anatomischer Anzeiger : official organ of the Anatomische Gesellschaft, vol. 191, no. 3, p. 248-259. http://dx.doi.org/10.1016/j.aanat.2009.02.007. PMid:19403284

KREUTZBERG, GW. and EMMERT, H., 1980. Glucose utilization of motor nuclei during regeneration: a [14C]2-deoxyglucose study. Experimental Neurology, vol. 70, no. 3, p. 712-716. http://dx.doi. org/10.1016/0014-4886(80)90197-1. PMid:7439305

LARRABEE, MG., 1980. Metabolic disposition of glucose carbon by sensory ganglia of 15-day-old chicken embryos, with new dynamic models of carbohydrate metabolism. Journal of Neurochemistry, vol. 35, no. 1, p. 210-231. http://dx.doi. org/10.1111/j.1471-4159.1980.tb12508.x. PMid:7005398

LARRABEE, MG., 1996. Partitioning of CO2 production between glucose and lactate in excised sympathetic ganglia, with implications for brain. Journal of Neurochemistry, vol. 67, no. 4, p. 17261734. http://dx.doi.org/10.1046/j.1471-4159.1996.67041726.x. PMid:8858959

MACHADO, VLA., WASSERMANN, GF. and MARQUES, M., 1991. In vitro effect of insulin on the uptake of glucose and $\alpha$-aminoisobutyric acid in the thyroid gland of the turtle (Chrysemys dorbigni). General and Comparative Endocrinology, vol. 82, no. 1, p. 8-13. http://dx.doi.org/10.1016/0016-6480(91)90290-M. PMid: 1874392

MAO, J., MAYER, DJ., HAYES, RL. and PRICE, DD., 1993. Spatial patterns of increased spinal cord membrane-bound protein kinase $\mathrm{C}$ and their relation to increases in 14C-2-deoxyglucose metabolic activity in rats with painful peripheral mononeuropathy. Journal of Neurophysiology, vol. 70, no. 2, p. 470-481. PMid:8410149.

MATSUMOTO, E. and ROSENBLUTH, J., 1988. Freeze-fracture study of the perineurium around frog dorsal root ganglia. Journal of Neurocytology, vol. 17, no. 4, p. 425-432. http://dx.doi. org/10.1007/BF01189800. PMid:3264016

MCDOUGAL, DB Jr., HOLOWACH, J., HOWE, MC., JONES, EM. and THOMAS, CA., 1968. The effects of anoxia upon energy sources and selected metabolic intermediates in the brains of fish, frog and turtle. Journal of Neurochemistry, vol. 15, no. 7, p. 
577-588. http://dx.doi.org/10.1111/j.1471-4159.1968.tb08956.x. PMid:4234032

MORAN, LB. and GRAEBER, MB., 2004. The facial nerve axotomy model. Brain Research. Brain Research Reviews, vol. 44, no. 2-3, p. 154-178. http://dx.doi.org/10.1016/j.brainresrev.2003.11.004. PMid:15003391

MORENO-FLORES, MT., OLAZÁBAL, UE. and KREUTZBERG, GW., 1997. Axotomy increases the expression of glucose-regulated protein $78 \mathrm{kDa}$ in rat facial nucleus. Experimental Neurology, vol. 146, no. 1, p. 10-16. http://dx.doi.org/10.1006/exnr.1997.6526. PMid:9225733

OHKITA, M., SAITO, S., IMAGAWA, T., TAKAHASHI, K., TOMINAGA, M. and OHTA, T., 2012. Molecular cloning and functional characterization of Xenopus tropicalis frog transient receptor potential vanilloid 1 reveal its functional evolution for heat, acid, and capsaicin sensitivities in terrestrial vertebrates. The Journal of Biological Chemistry, vol. 287, no. 4, p. 2388-2397. http://dx.doi.org/10.1074/jbc.M111.305698. PMid:22130664

OLIVEIRA, AL., 2001. Apoptosis of sensory neurons and satellite cells after sciatic nerve transection in C57BL/6J mice. Brazilian Journal of Medical and Biological Research, vol. 34, no. 3, p. 375-380. http://dx.doi.org/10.1590/S0100-879X2001000300012. PMid:11262589

PARTATA, WA., CERVEIRA, JF., XAVIER, LL., VIOLA, GG. and ACHAVAL, M., 2002. Sciatic nerve transection decrease substance P immunoreactivity in the lumbosacral spinal cord of the frog (Rana catesbeiana). Comparative Biochemistry and Physiology. Part B, Biochemistry \& Molecular Biology, vol. 131, no. 4, p. 807-814. http://dx.doi.org/10.1016/S1096-4959(02)000416. PMid: 11923093

PELLERIN, L. and MAGISTRETTI, PJ., 2012. Sweet sixteen for ANLS. Journal of Cerebral Blood Flow and Metabolism: official journal of the International Society of Cerebral Blood Flow and Metabolism, vol. 32, no. 7, p. 1152-1166. http://dx.doi. org/10.1038/jcbfm.2011.149. PMid:22027938

PENICNAK, AJ. and DUNLAP, DG., 1962. Localization and distribution of motor neurons in the lumbar enlargement of the spinal cord in Rana pipiens. Proceedings of the South Dakota Academy of Sciences, vol. 41, p. 113-118.

RIGON, F., ROSSATO, D., AULER, VB., DAL BOSCO, L., FACCIONI-HEUSER, MC. and PARTATA, WA., 2013. Effects of sciatic nerve transection on ultrastructure, NADPH-diaphorase reaction and serotonin-, tyrosine hydroxylase-, c-Fos-, glucose transporter 1- and 3-like immunoreactivities in frog dorsal root ganglion. Brazilian Journal of Medical and Biological Research, vol. 46, no. 6, p. 513-520. http://dx.doi.org/10.1590/1414431X20132853. PMid:23739744

ROCHA, PL. and BRANCO, LGS., 1998. Seasonal changes in the cardiovascular, respiratory and metabolic responses to temperature and hypoxia in the bullfrog Rana catesbeiana. The Journal of Experimental Biology, vol. 201, no. Pt 5, p. 761-768. PMid:9542154.

STEVENS, CW., 2004. Opioid research in amphibians: a unique perspective on mechanism of opioid analgesia and the evolution of opioid receptors. Brain Research. Brain Research Reviews, vol. 46, no. 2, p. 204-215. http://dx.doi.org/10.1016/j. brainresrev.2004.07.003. PMid:15464208

STEVENS, CW., BRASEL, CM. and MOHAN, S., 2007. Cloning and bioinformatics of amphibian mu, delta, kappa, and nociceptin opioid receptors expressed in brain tissue: evidence for opioid receptor divergence in mammals. Neuroscience Letters, vol. 419, no. 3, p. 189-194. http://dx.doi.org/10.1016/j.neulet.2007.04.014. PMid: 17452077
STEVENS, CW., MARTIN, KK. and STAHLHEBER, BW., 2009. Nociceptin produces antinociception after spinal administration in amphibians. Pharmacology, Biochemistry, and Behavior, vol. 91, no. 3, p. 436-440. http://dx.doi.org/10.1016/j.pbb.2008.08.022. PMid: 18804120

SAITO, S., NAKATSUKA, K., TAKAHASHI, K., FUKUTA, N., IMAGAWA, T., OHTA, T. and TOMINAGA, M., 2012. Analysis of transient receptor potential ankyrin 1 (TRPA1) in frogs and lizards illuminates both nociceptive heat and chemical sensitivities and coexpression with TRP vanilloid 1 (TRPV1) in ancestral vertebrates. The Journal of Biological Chemistry, vol. 287, no. 36, p. 30743-30754. http://dx.doi.org/10.1074/jbc. M112.362194. PMid:22791718

SCHURR, A., PAYNE, RS., MILLER, JJ. and RIGOR, BM., 1999. Study of cerebral energy metabolism using the rat hippocampal slice preparation. Methods (San Diego, Calif.), vol. 18, no. 2, p. 117-126. http://dx.doi.org/10.1006/meth.1999.0765. PMid:10356342

SCHURR, A. and PAYNE, RS., 2007. Lactate, not pyruvate, is neuronal aerobic glycolysis end product: an in vitro electrophysiological study. Neuroscience, vol. 147, no. 3, p. 613-619. http://dx.doi.org/10.1016/j.neuroscience.2007.05.002. PMid:17560727

SCHURR, A. and GOZAL, E., 2012. Aerobic production and utilization of lactate satisfy increased energy demands upon neuronal activation in hippocampal slices and provide neuroprotection against oxidative stress. Frontiers in Pharmacology, vol. 13, p. 2-96. PMid:22275901.

SINGER, P. and MEHLER, S., 1980. 2-deoxy[14C]glucose uptake in the rat hypoglossal nucleus after nerve transection. Experimental Neurology, vol. 69, no. 3, p. 617-626. http://dx.doi. org/10.1016/0014-4886(80)90055-2. PMid:7409067

SPARROW, JR. and KIERNAN, JA., 1981. Endoneurial vascular permeability in degenerating and regenerating peripheral nerves. Acta Neuropathologica, vol. 53, no. 3, p. 181-188. http://dx.doi. org/10.1007/BF00688020. PMid:7223363

SUTHERLAND, RM. and NUNNEMACHER, RF., 1974. Fibers in the ventral spinal nerves of the frog. The Journal of Comparative Neurology, vol. 156, no. 1, p. 39-47. http://dx.doi.org/10.1002/ cne.901560105. PMid:4545862

TORRES, ILS., GAMARO, GD., SILVEIRA-CUCCO, SN., MICHALOWSKI, MB., CORRÊA, JB., PERRY, ML. and DALMAZ, C., 2001. Effect of acute and repeated restraint stress on glucose oxidation to $\mathrm{CO} 2$ in hippocampal and cerebral cortex slices. Brazilian Journal of Medical and Biological Research, vol. 34, no. 1, p. 111-116. http://dx.doi.org/10.1590/S0100879X2001000100013. PMid:11151035

WARREN, DE. and JACKSON, DC., 2005. The role of mineralized tissue in the buffering of lactic acid during anoxia and exercise in the leopard frog Rana pipiens. The Journal of Experimental Biology, vol. 208, no. 6, p. 1117-1124. http://dx.doi.org/10.1242/ jeb.01490. PMid:15767312

WILSON, MC., JACKSON, VN., HEDDLE, C., PRICE, NT., PILEGAARD, H., JUEL, C., BONEN, A., MONTGOMERY, I., HUTTER, OF. and HALESTRAP, AP., 1998. Lactic acid efflux from white skeletal muscle is catalyzed by the monocarboxylate transporter isoform MCT3. The Journal of Biological Chemistry, vol. 273 , no. 26, p. 15920-15926. http://dx.doi.org/10.1074/ jbc.273.26.15920. PMid:9632638

JIANG, Y. and JAKOBSEN, J., 2010. Different apoptotic reactions of dorsal root ganglion A- and B-cells after sciatic nerve axotomy: effect of p75 neurotrophin receptor. Chinese Medical Journal, vol. 123, no. 19, p. 2695-2700. PMid:21034655. 